Ritrýnd grein birt 31. desember 2018

\title{
Siðfræði í bókmenntakennslu
}

\author{
Dóra Björg Sigurðardóttir
}
Abstract
Um höfundinn
About the author
Heimildir

Rannsóknin sem hér segir frá er hluti af stærra rannsóknarverkefni um siðfræði í bókmenntakennslu. Í pessari grein er sjónum beint að reynslu íslenskukennara af pví að kenna unglingum í 9. og 10. bekk í grunnskóla Íslendingasöguna Laxdælu með sérstakri áherslu á siðferðileg hugtök og siðferðilegar pælingar tengdar sögunni. Leitað er svara við tveimur spurningum sem eru: i. Hvernig pykir kennurum pað fara saman að kenna um siðferði og að kenna bókmenntir eins og Laxdæla sögu?

ii. Hvaða tilgang sjá kennarar með pví að kenna Laxdæla sögu?

Spurningunum er svarað með vísun í viðtalsrannsókn og tilraunakennslu sem fór fram í premur grunnskólum. Gagnasöfnun fólst í 10 viðtölum við fimm kennara og vettvangsathugunum í kennslustundum hjá peim sem varpa frekara ljósi á viðhorf kennaranna. Kennurunum til halds og trausts var útbúið verkefnahefti par sem sérstök áhersla var lögð á hið siðferðilega sjónarhorn og dygðir og lesti sögupersónanna í Laxdælu.

Í viðtölum við kennarana kom fram hvernig peir settu siðfræðiverkefnið í samhengi við hugmyndir sínar um tilgang pess að kenna bókmenntir eins og Laxdæla sögu. Í stórum dráttum má segja að svarið við seinni spurningunni sé að kennarar fari upp fjögur prep til pess að tengja nemendur sögunni, sem miða öll að pví að njóta bókmenntanna. Í raun birtist parna viðhorfí pá veru að bókmenntir eigi að vera bæði mannbætandi og proskandi á listrænan hátt og pær hafi gildi í sjálfu sér.

Samkvæmt kennurunum hjálpaði tengingin við siðfræði og pað að skoða persónur og gjörðir út frá sjónarhorni dygðanna nemendum við að setja sig í spor persónanna og pað dýpkaði fyrir peim söguna. Fyrri spurningunni má pví svara pannig að skipuleg umfjöllun um siðferðileg hugtök og orðaforða og samræða um siðferðileg efni geti, að mati kennaranna sem tóku pátt í verkefninu, aukið áhuga unglinga á bókmenntum og hjálpað peim að skilja bókmenntatexta.

Efnisorð: Laxdæla saga, bókmenntakennsla á unglingastigi, siðferðilegt uppeldi, siðferðilegur orðaforði, siðferðilegar dygðir, lýðræði.

\section{Inngangur}

Viðtalsrannsóknin sem hér segir frá er hluti af stærra rannsóknarverkefni sem fjallar um pað hvort hægt sé að nota bókmenntakennslu til að efla siðferði nemenda á unglingastigi og um leið hvort umfjöllun um siðferðileg hugtök og samræða um siðferðileg efni geti aukið áhuga unglinga á bókmenntum og hjálpað peim að skilja bókmenntatexta. 
Stuttlega er sagt frá verkefninu í fyrstu greininni í pessu sérriti (Atli Harðarson, Ólafur Páll Jónsson, Róbert Jack, Dóra Björg Sigurðardóttir og Sigrún Sif Jóelsdóttir, 2018). Í pessari grein verður sjónum beint að upplifun og reynslu fimm íslenskukennara af pví að kenna unglingum í 9. og 10. bekk í grunnskóla Íslendingasöguna Laxdælu með sérstakri áherslu á siðferðileg hugtök og siðferðilegar pælingar tengdar sögunni. Leitað verður svara við tveimur spurningum: i. Hvernig pykir kennurum pað fara saman að kenna um siðferði og að kenna bókmenntir eins og Laxdæla sögu? ii. Hvaða tilgang sjá kennarar með pví að kenna Laxdæla sögu?

\section{Lýðræðisleg húmanísk menntun}

„Баð er engin leið að gera manninn sem skynveru að skynsemisveru nema með pví að koma honum fyrst í kynni við fegurðina“" (Schiller, 2006, bls. 206). Svona komst Friedrich Schiller (1759-1805) аð orði fyrir liðlega hundrað árum. Hann lagði áherslu á menntagildi listanna og mikilvægi pess að nám væri leikur og að leikhvöt manna fengi notið sín par sem hún gegndi mikilvægu hlutverki fyrir listina að lifa. Schiller sagði enn fremur að hið fagurfræðilega, listin, ætti ekki einungis að vera umgjörð, afpreying eða siðapredikun heldur tengdi hún saman skynsemina og skynjunina og gerði pannig manninum „kleift að gera úr sjálfum sér pað sem hann kærir sig um [...] honum [...] hlotnast að fullu frelsi til að vera pað sem hann skal vera“ (Schiller, 2006, bls. 195). Pannig taldi hann ímyndunaraflið rjúfa mörkin á milli veruleikans og hins mögulega og að í frjálsum leik og listum gæfist manneskjunni frelsi til að proskast til fulls.

Í lok átjándu aldar var Schiller frumkvöðull peirra húmanísku hugmynda að menntun ætti að proska manneskjuna alla og par hefðu listir og leikur mikilvægu hlutverki að gegna. Tilfinningar ættu ekki að hafa minna vægi en rökhugsun og pekkingaratriði sem upplýsingin hélt á lofti en hann taldi að til pess að mennta manneskjuna alla pyrfti að hlúa að öllum eðlispáttum hennar. Á 19. öld tóku húmanistar sem urðu fyrir áhrifum frá Schiller undir pessar hugmyndir um að listir og bókmenntir væru mannbætandi og proskandi (Atli Harðarson, 2011). Dessi sjónarmið voru stundum tengd skólum fyrir yfirstétt frekar en alpýðu en pau hafa samt sem áđur átt sér málsvara meðal ólíkra stétta og félagshópa. Einn talsmaður svipaðra sjónarmiða var til dæmis Du Bois sem talaði máli síns fólks, bandarískra blökkumanna, fyrir einni öld. Hann lagði áherslu á að bókmenntir og listir, svokölluð hámenning, væri ekki síður mikilvæg til að mennta börn en menntun sem hefði eingöngu notagildi að leiðarljósi, og taldi raunar að pað fælist í pví lítilsvirðing að koma fram við manneskjur einungis út frá hugmyndum um nytsamlega menntun (Du Bois, 2015).

Margir menntaheimspekingar tuttugustu aldar, eins og t.d. Maxine Greene (1973) og Martha Nussbaum (1997, 2010), hafa einnig lagt áherslu á mikilvægi lista og menningar sem bæði inntak og markmið menntunar fremur en að líta svo á að menntun hafi fyrst og fremst hagnýtt gildi fyrir atvinnulífið. Dær halda pví fram að mikilvægt sé að öðlast skilning á mannlegri reynslu af ólíkum toga í tengslum við pá flóknu veröld sem við lifum í; maðurinn geti ekki tengt sig veröldinni í kringum sig með staðreyndum einum og rökum. Đær benda á að meðal nauðsynlegra hæfileika nemenda sé m.a. ímyndunarafl og geta til að sjá fyrir sér hvernig sé að vera einhver annar; setja sig í spor annarra manneskja og vera læs á sögur peirra með pví að skilja tilfinningar peirra, óskir og prár, hvort sem um sé að ræða reynslu liðinna kynslóða, aðstæður fólks sem býr annars staðar á hnettinum eða hugarheim pess sem lifir og hrærist við aðrar aðstæður en við sjálf.

Martha Nussbaum (2010) veltir pví fyrir sér hvort leikur og samhygð séu ef til vill einhver besta lýðræðismenntunin; menntun sem stuðli að pví að fólk sjái heiminn með augum annarra. Niðurstaða hennar er sú að samfélagið hafi pörf fyrir menntun par sem lögð sé rækt við gildi eins og mannvirðingu og mannhelgi, að velferð hverrar manneskju skipti máli og að líta skuli á annað fólk sem jafningja pótt pað sé ólíkt manni sjálfum. Í samræmi við petta lagði hún áherslu á að mennta ,innra auga“ nemandans í gegnum listir og húmanísk fög sem hæfa aldri og proska og hjálpa nemendum pannig að mynda tengsl við fólk af ólíku kyni, kynpáttum og pjóðerni. 
Til að vera borgari í heimi margbreytileikans parf skilning á lífi fólks sem er öðruvísi. Í slíkri menntun felst að læra að lifa með öðrum með virðingu fyrir pví sem er framandi (Nussbaum, 2010, bls. 108).

Nussbaum taldi pað ekki síður pátt í lýðræðislegri, húmanískri menntun að örva nemendur til að hugsa og móta sjálfa sig í stað pess að peir beygi sig undir yfirvald og hefðir eða fyrir fram ákveðin markmið kennsluefnis. Рað pyrfti að vekja pá til umhugsunar og auka skilning peirra á málefnum sem snerta bæði pá og aðra og gefa peim tækifæri til að lifa sig inn í hlutina og uppgötva sjálfir og laða pannig fram hugmyndir peirra um ýmis álitamál mannlegs lífs.

Áhersla á lýðræði og mannréttindi, jafnrétti og sköpun í núgildandi Aðalnámskrá samrýmist vel peim markmiðum sem Nussbaum setur húmanískri menntun. Dar segir til dæmis um jafnréttismenntun: „Markmið jafnréttismenntunar er að skapa tækifæri fyrir alla til að proskast á eigin forsendum, rækta hæfileika sína og lifa ábyrgu lífi í frjálsu samfélagi í anda skilnings, friðar, umburðarlyndis, víðsýnis og jafnréttis“" (Mennta- og menningarmálaráđuneytið, 2016, bls. 15). Og um sköpun segir meðal annars:

Sköpun er að uppgötva, njóta, örva forvitni og áhuga, virkja ímyndunarafl og leika sér með möguleika. Leikur er mikilvæg námsaðferð og opnar víddir par sem sköpunargleði barna og ungmenna getur notið sín. Hamingja og gleði liggja í pví að finna hæfileikum sínum farveg og fá að njóta sín sem einstaklingur og hluti af heild. Sköpun er mikilvægur grunnur að pví að horfa til framtíðar og móta sér framtíðarsýn, taka pátt í mótun lýðræðissamfélags og skapa sér hlutverk innan pess (Mennta- og menningarmálaráđuneytið, 2016, bls. 1617).

Bókmenntaverk eru kjörin til að auka skilning nemenda á siðferði og mannlífinu í öllum sínum margbreytileika. Pau hafa gjarnan verið notuð til að víkka út sjóndeildarhring nemenda, innræta peim ákveðnar hugmyndir um réttlæti og fjalla um pá sem minna mega sín í samfélaginu (Kristján Jóhann Jónsson, 2016, bls. 65-69; Dagný Kristjánsdóttir, 2010).

Í Aðalnámskrá segir um bókmenntakennslu: „Í bókmenntum finna ungir lesendur fyrirmyndir og geta sett sig í spor persóna. Dannig getur bókmenntakennsla í skólum stuðlað að sterkari sjálfsmynd nemenda og kennt peim umburðarlyndi í garð ólíkra menningarsamfélaga og minnihlutahópa“ (Mennta- og menningarmálaráðuneytið, 2016, bls. 99). Par er einnig kveðið á um að nemendur kynnist menningararfi Íslendinga í gegnum bækur og geti lesið texta með gagnrýnum huga og „ráði yfir ýmsum leiðum til skilnings og túlkunar“. Í lok 10. bekkjar á nemandi að geta „valið sér lesefni til gagns og ánægju og komið fram sem sjálfstæður lesandi sem gerir sér grein fyrir gildi pess að lesa“ (Mennta- og menningarmálaráđuneytið, 2016, bls. 102103). Umfjöllun í Aðalnámskrá um bókmenntakennslu fellur pví vel að hugmyndum Schillers á 18. öld, Du Bois fyrir hundrað árum og Greene og Nussbaum í seinni tíð.

Bókmenntakennsla í íslenskum skólum hefur lítið verið rannsökuð (Kristján Jóhann Jónsson og Ásgrímur Angantýsson, 2018, bls. 126) en líkast til hafa margir bókmenntakennarar haft pað að markmiði að auka skilning nemenda á siðferði og mannlífi, hver á sinn hátt, samhliða pví að miðla pekkingu á bókmenntunum sjálfum, sögu peirra, próun og einkennum. Í spánnýrri rannsókn á íslenskukennslu í grunnskólum og framhaldsskólum (Kristján Jóhann Jónsson og Ásgrímur Angantýsson, 2018) birtast sjónarmið hjá kennurum sem ríma vel við pað sem hér hefur komið fram. Bókmenntakennarar sem rætt var við telja að pað sé mikilvægt að börn njóti pess að lesa bækur, pað sé mikilvægt að virkja ímyndunarafl peirra og sköpun og að pau læri að setja sig í spor annarra (Kristján Jóhann Jónsson og Arngrímur Angantýsson, 2018, bls. 97-100).

Degar spurt var um menntunar- og menningarlegt gildi bókmennta svöruðu kennararnir með svipuðum hætti. Deir vilja að nemendur öðlist ,innsýn í mannlíf og samúð með öðru fólki, líka víðsýni og umburðarlyndi sem nýtist peim í lífinu“ (Kristján Jóhann Jónsson og Ásgrímur Angantýsson, 2018, bls. 118). Pá finnst kennurum mikilvægt að bókmenntir miðli 
menningararfinum. Í pví samhengi virðist almennt ríkja sátt um pað að kenna Íslendingasögurnar í grunn- og framhaldsskólum og pað kemur einnig fram í rannsókninni að meirihluti nemenda virðist hafa gaman af lestri miðaldabókmenntanna og peim veruleika sem pær segja frá (Kristján Jóhann Jónsson og Arngrímur Angantýsson, 2018, bls. 127). Loks segja kennarar að gildi bókmennta felist í pví að nemendur læri að lesa í merkingu á „milli línanna“ sem pýðir væntanlega að hafa skilning á, túlka og draga sínar eigin ályktanir af pví sem textinn segir (Kristján Jóhann Jónsson og Ásgrímur Angantýsson, 2018, bls.118).

Баð er pó ekki skýrt hvernig petta fer fram; hvernig tekst að tengja nemendur við textann, hvernig kennari stuðlar að pví að nemandi setji sig í spor annarra og síðast en ekki síst, hvernig nemendur verða að sjálfstæðum lesendum sem öðlast skilning, túlka og draga sínar eigin ályktanir. Í kaflanum um bókmenntir og bókmenntakennslu í umræddri íslenskurannsókn segja höfundar (Dagný Kristjánsdóttir, Jón Yngvi Jóhannsson, Brynhildur Pórarinsdóttir og Kristján Jóhann Jónsson) að ekki sé sérstaklega hjálplegt pegar kennarar segist leggja áherslu á skilning og túlkun án frekari skýringa á pví hvernig pað sé gert. Niðurstaða rannsóknar peirra er að í bókmenntakennslu í grunnskólum sé lítil og ómarkviss áhersla á bókmenntafræðihugtök og önnur greiningarhugtök (Kristján Jóhann Jónsson og Ásgrímur Angantýsson, 2018, bls. 98-99, 116 og 130).

Ef litið er til ákveðinna kennslubóka má sjá vísbendingar um pað hvernig hægt er að laða fram sjónarmið nemenda, túlkun peirra og skilning á bókmenntaarfinum. Í ýmsum skólaútgáfum Íslendingasagnanna, kennsluleiðbeiningum Brynhildar Dórarinsdóttur (2002) með Njálu og nú síðast í útgáfum Menntamálastofnunar á bæði Laxdæla sögu (2017) og Gísla sögu (2017) eru spurningar í lok hvers kafla sem miða að pví að fá nemendur til pess að fást við fleira en staðreyndir textans, svo sem að ræða ýmis álitamál, lesa á milli línanna og mynda sér sjálfstæðar skoðanir á persónum og athöfnum peirra.

Enn sterkar er kveðið að í bókinni Lifsleikni Njálu - Siðfreðileg umhugsunarefni fyrir ungt fólk eftir Arthúr Björgvin Bollason (2010) sem fjallar sérstaklega um Njálu út frá sjónarhorni siðferðis; dygðum og löstum, atferli og breytni persóna í sögunni. Markmiðið er „að komast nær persónum sögunnar, átta sig betur á peim fjölbreyttu manngerðum sem höfundur teflir fram fyrir augum okkar [...] skilja hvað pað er sem ræður mannlegri breytni, háttalagi fólks yfirleitt." Enn fremur er ætlunin að par með geti ,persónur Njálu hugsanlega stuðlað að pví að við eigum auðveldara með að skilja hvað pað er sem skilur á milli rangrar og réttrar, eða góðar og slæmrar breytni““ (Arthúr Björgvin Bollason, 2010, bls. 9).

Í Aðalnámskrá grunnskóla er ekki beinlínis minnst á að proska siðferđisvitund nemenda í tengslum við bókmenntalestur pó margt af pví sem áđur hefur komið fram sé auðvelt að tengja við siðferði, samhygð og réttlæti. Um hæfniviðmið í bókmenntakennslu í framhaldsskóla segir hins vegar að „,nemandi skuli geta hagnýtt pá pekkingu og leikni sem hann hefur aflað sér til að: sýna proskaða siðferðisvitund, víðsýni, sköpunarhæfni og samlíðan í málflutningi sínum, umfjöllun og verkum“ (Mennta- og menningarmálaráđuneytið, 2015, bls. 92).

Siðgæðisvitund er samt sem áður meðal áherslupátta í grunnskólalögum, og útleggst pannig í Aðalnámskrá að nemendur ,efli siðferðisproska sinn og geti sett sig í spor annarra. Tilfinningar og reynsla nemenda gegna lykilhlutverki í próun siðferðiskenndar peirra sem felst í pví að peir tileinki sér hvað telst rétt og rangt, gott og slæmt í breytni fólks. Nemendur purfa að taka siðferðilega afstöðu til álitamála og virða rétt hvers og eins til að láta skoðanir sínar í ljós [...] og bera virðingu fyrir öðrum“ (lög um grunnskóla nr. 91/2008; Mennta- og menningarmálaráðuneytið, 2016, bls. 37).

Til pess að skoða siðferði í bókmenntaverkum og hegðun og breytni sögupersóna á ígrundaðan hátt parf í senn að vinna með inntak og umgjörð námsins. Ef vinna á markvisst með siðferðilegt inntak bókmenntanna og gefa nemendum færi á að kafa undir yfirborðið - skoða athafnir og persónur af einhverri dýpt - parf að vinna með greiningarhugtök og sameiginlegan siðferðilegan 
orðaforða. En orðaforðinn einn og sér nægir ekki heldur er nauðsynlegt að virkja tilfinningar, forvitni og ímyndunarafl nemenda og leyfa peim að leita sjálfir að svörunum, eiga opnar samræður um persónur og atburði, leika sér með möguleika og draga sínar eigin ályktanir út frá peim. Ваð аð hugsa með öðrum er æfing í lýðræðislegri pátttöku, í frjálsum skoðanaskiptum og sjálfstæðum efnistökum en ekki síður pví að sjá heiminn með augum annarra, uppgötva, hlusta á og virða tilfinningar og sjónarmið annarra manneskja og vinna saman að ákveðnu markmiði. Í opinni samræðu gefst nemandanum færi á að njóta sannmælis og leggja sitt af mörkum sem einstaklingur en vera um leið mikilvægur hluti af heild.

Með bókmenntakennslu gefst ákveðið ráðrúm til að fjalla um siðferðileg álitamál án pess að pað tengist nemendum sjálfum eða verið sé með beina innrætingu í siðferðismálum. Dað gefur nemendum fjarlægð til að móta sjálfa sig og velta fyrir sér hvernig megi lifa vel í samfélagi við aðra (Ólafur Páll Jónsson, 2018). Og pað að vera ekki bundinn við fyrir fram gefin svör en hafa skilning á sameiginlegum orðaforða um siðferði gefur nemendum tækifæri til að gera eigin uppgötvanir og sjá persónur og mannkosti peirra frá mörgum hliðum (Atli Harðarson, 2018).

Í pví ljósi er áhugavert að skoða afstöđu nemenda í íslenskurannsókninni par sem peir segja sjálfir að sá páttur í bókmenntanáminu sem peir kunni best að meta sé umræður um bókmenntaverkin og að pær séu pað sem peir læri mest af. Deir eru einnig ánægðir ef bókmenntakennslan er tengd við aðra listmiðla og skapandi verkefni og ,hæla kennurum fyrir fjölbreyttar námsleiðir og að virkja sköpunarkraft“ (Kristján Jóhann Jónsson og Arngrímur Angantýsson, 2018, bls. 121). Ef til vill eru pað slíkar umræður um bókmenntaverk sem vekja til umhugsunar, skapa vettvang fyrir ímyndunaraflið til að rjúfa mörkin milli veruleikans og hins mögulega (í frjálsum leik og listum) og örva nemendur til að hugsa sjálfir um ýmis álitamál mannlegs lífs; slíkar umræður gefa peim frelsi til að proskast sem manneskjur.

\section{Rannsóknaraðferðir}

Undirbúningur að rannsóknarverkefninu hófst haustið 2016 pegar fengust til samstarfs fimm kennarar úr premur grunnskólum (Atli Harðarson o.fl., 2018). Síðan pá hafa peir kennarar einnig verið nokkurs konar samstarfsaðilar kennsluverkefnisins. Í samráði við kennara var bókmenntaverk, aldur nemendahóps og kennslutímabil valið og undirbúningur að kennsluverkefninu hafinn. Kennsluverkefnið fór síðan fram haustönn 2017 yfir sex vikna tímabil frá október og fram í miðjan nóvember.

Íslendingasagan Laxdæla varð fyrir valinu og ákveðið var að kenna hana á sex vikna tímabili haustið 2017, bæði 9. og 10. bekk, í alls 10 nemendahópum/bekkjum. Notuð var einfölduð útgáfa Laxdælu sem Gunnar Karlsson bjó út fyrir grunnskóla. Önnur útgáfa bókarinnar var í vinnslu hjá Menntamálastofnun petta misseri en rannsakendur fengu leyfi til að fjölfalda næstum fullgerða bók með pví skilyrði að henda fjölritinu að verkefninu loknu.

Á fundum með kennurum var tilhögun kennslunnar rædd og einnig ákveðið að rannsóknarteymið myndi útbúa verkefnahefti (námsefni og kennsluleiðbeiningar) til að styðja kennarana í að beina sjónum að siðferðilegum páttum sögunnar og draga fram tilteknar siðferðilegar dygðir sem ræett yrði um í kennslustundum. Róbert Jack útbjó heftið og hugmyndir sem að baki pví liggja eru skýrðar í tveim greinum eftir hann í pessu sérriti Netlu (Róbert Jack, 2018a, 2018b). Heftið er nú aðgengilegt á vef Menntamálastofnunar (Róbert Jack, 2018c). Í heftinu eru meðal annars verkefni par sem siðferðilegum hugtökum og orðaforða um dygðir og lesti er markvisst beitt til að fjalla um atvik og persónur í Laxdæla sögu. Í verkefnaheftinu var lögð áhersla á átta dygðir: prautseigju, örlati, heiðarleika, sjálfsaga, hugrekki, karleika, sanngirni og sáttfýsi en einnig var að finna langan lista yfir dygðir sem kennarar gátu notað að vild. Í upphafi var pað svo í höndum hvers kennara að kynna pessar dygðir og finna efnistök sem hæfðu kennslunni. 
Í verkefnaheftinu voru viðfangsefni eins og:

Flokkaðu mannkosti í tvo flokka:

a) 1. eitthvað sem maður er góður í (hæfileikar) t.d. góður að lesa og

b) 2. góðir eiginleikar sem hafa með samskipti við aðra að gera t.d. hjálpsemi

Einnig voru ýmsar æfingar sem snerust um pað hvaða dygðum nemendur vildu búa yfir sjálfir, hvað teldist dygðugt líf, hvaða persónur í kvikmyndum peir teldu dygðugar o.s.frv. Par voru líka dæmi um skilgreiningar á dygðum, t.d.

hugrekki: að hafa styrk og vilja til að gera pað sem er rétt jafnvel pótt maður kunni að vera hræddur.

Sagan sjálf, Laxdæla, var aðalkennsluefnið en verkefnaheftið mótaði yfirferðina par sem sagan var lesin með hliðsjón af verkefnum sem fjölluðu um siðferðilegar dygðir. Pannig voru sem sagt dregnir fram með skipulögðum hætti pættir sem tengdust mannkostum persónanna og siðlegri breytni. Sem dæmi um spurningar tengdar köflunum má nefna: „Hver sýnir hugrekki í kaflanum? Hvernig sýnir viðkomandi hugrekki? Er munur á hugrekki til forna og nú?" Lagt var upp með að nálgast viðfangsefnið á skipulegan hátt og kanna hvernig samræða um bókmenntatextann gæti glætt skilning nemenda á pessum hugtökum og atriðum sem skipta máli fyrir siðferði fólks.

Allir kennararnir fylgdu endurgerð Gunnars Karlsonar á sögunni og verkefnahefti Róberts Jack í megindráttum. Deir notuðu tíma í upphafi til að kynna nemendum dygðirnar og hina siðfræðilegu nálgun og mátuðu svo pessar átta dygðir við persónur og atburði í fyrstu köflum bókarinnar. Í verkefnaheftinu voru spurningar úr hverjum kafla fyrir sig. Баð var bæði hægt að vinna með pessar spurningar skriflega og munnlega, kennarinn sjálfur eða nemendurnir gátu haft pær sem hjálpargagn eða sem meginprád. Kennurum var sem sagt í sjálfsvald sett hvernig peir notuðu heftið og höguðu kennslu sinni.

Gerð var viðtalsrannsókn meðal kennaranna samhliða tilraunakennslunni og var eigindlegum aðferðum beitt við úrvinnslu gagnanna. Gagnasöfnun fólst í 10 viðtölum við pá fimm kennara sem tóku pátt í rannsókninni. Sömu kennarar voru einnig heimsóttir í kennslustundir og par skráðar vettvangsnótur til að varpa frekara ljósi á upplifun kennaranna af kennslunni, virkni nemendanna og gang verkefnisins. Fyrri fimm viðtölin voru tekin um miðbik kennslutímans, á sama tíma og fylgst var með kennslustundum hjá kennurunum, en seinni viðtölin eftir lok kennslutímans. Viðtölin voru hálfopin einstaklingsviðtöl. Spurningarnar byggðust á fyrirframgerðum viðtalsramma par sem áhersla var lögð á meginpætti rannsóknarinnar sem fram komu í markmiðum hennar og rannsóknarspurningum en gáfu kennurunum samt sem áður svigrúm til að koma sjónarmiðum sínum og upplifun að og ræða á opinskáan hátt um pað sem peim lá á hjarta og fá pannig hugsanlega meiri dýpt í viðfangsefnið.

Viðtölin voru hljóðrituð á vettvangi og síðan afrituð orðrétt. Fyrri viðtölin við kennarana voru 40 mínútur til ein og hálf klukkustund að lengd en seinni viðtölin voru mun styttri, 18 til um 40 mínútur. Dau voru sérstaklega notuð til að fylgja eftir, staðfesta og spyrja nánar út í atriði sem komu fram í fyrri viðtölunum. Notuð voru „gervinöfn“ við skráningu viðtala og vettvangsathugana til pess að virða trúnað.

Við söfnun og greiningu rannsóknargagnanna var stuðst við kerfisbundin vinnubrögð og stöðuga greiningu eigindlegra rannsóknargagna (Creswell og Poth, 2018; Charmaz, 2014). Rannsóknargögnin voru yfirfarin og flokkuð með ítarlegri kóðun í fyrstu, sem er grundvöllur pess að hægt sé að álykta út frá peim, en síðan var notuð pemakódun. Ekki var sett fram tilgáta um viðfangsefnið 1 upphafi rannsóknarinnar heldur var notuð aðleiðsla. Markviss ígrundun var notuð við úrvinnslu viðtalanna til að skoða upplifun rannsakanda, tengsl og viðhorf til 
viðfangsefnisins og til að fylgjast með próuninni sem varð eftir pví sem rannsókninni vatt fram, gögnin urðu viðameiri og skilningur á viðfangsefninu jókst (Creswell og Poth, 2018; Charmaz, 2014).

Áherslan í hinum eigindlegu aðferðum er á kennurunum sjálfum sem uppsprettu og forsendu pess hvernig kennsluverkefnið fór fram. Deir voru samstarfsaðilar frá upphafi og gáfu leyfi sitt til athugana og viðtala. Áhrif peirra á kennsluverkefnið eru pví óumdeild en ekki er heldur útilokað að fundir með rannsóknarteyminu par sem fram fóru umræður um Laxdæla sögu og kennsluaðferðir og síðan íhlutun verkefnaheftisins hafi haft áhrif á bæði störf og viðhorf peirra sjálfra yfir tímabilið og pví sé um gagnkvæm áhrif að ræða. Kennararnir skrifuðu undir bréf um upplýst sampykki áður en viðtölin hófust og gagnkvæmum trúnaði og heilindum rannsakanda og kennara var lofað. Í upphafi viðtalanna voru pau fjögur meginatriði sem liggja til grundvallar peim siðareglum sem gilda um svona rannsóknir kynnt. Dau eru: virðing, skaðleysi, velgjörðir/ gagnsemi og réttlæti (Sigurður Kristinsson, 2013; Snæfríður Egilson, 2006). Rannsóknin var tilkynnt til Persónuverndar og skráð hjá Vísindasiðanefnd Háskóla Íslands. Öll gögn eru ópersónugreinanleg.

Kennararnir fimm sem tóku pátt í rannsókninni voru konur sem kenndu íslensku á unglingastigi. Dær voru á aldursbilinu milli prítugs og sextugs, allar menntaðir íslenskukennarar en með mjög mismikla kennslureynslu, allt frá tveggja til priggja ára og í y fir brjátíu ára reynslu. Dær hafa einnig mismunandi reynslu af og pekkingu á kennslu Íslendingasagna. Engin peirra er heimspekikennari eða hefur kennt siðfræði áður en tvær peirra hafa notað heimspekilegar samræður í kennslu. Kennararnir kenndu einum til premur bekkjum Íslendingasöguna Laxdæla sögu, sumar sínum umsjónarbekk eða nemendum sem pær pekktu vel, aðrar kenndu nemendahópum sem pær höfðu ekki kennt áður. Kennurunum voru gefin eftirfarandi gervinöfn:

Eva María kennari í Hamravíkurskóla.

Guðfinna kennari í Straumfjarðarskóla

Hrefna kennari í Viðvíkurskóla.

Svandís kennari í Straumfjarðarskóla.

Tinna kennari í Hamravíkurskóla.

\section{Niðurstöður}

Úrvinnsla viðtalanna er hér rakin undir fjórum pemaflokkum. Í viðtölunum við kennarana kemur fram hvernig peir setja siðfræðiverkefnið í samhengi við hugmyndir sínar um tilgang pess að kenna bókmenntir eins og Íslendingasöguna Laxdæla sögu.

Í öllum viðtölunum kom fram sú skoðun kennaranna að eitt meginmarkmið bókmenntalesturs sé að njóta. Detta kemur fram í pví að peim finnst mikilvægt að nemendum pyki gaman að lesa og gott að hlusta, fái áhuga á lestri bókmennta og hafi ástríðu fyrir slíkum lestri, en pað sé einnig grundvöllur pess að komast inn í söguna, geta sett sig í spor sögupersóna og að lokum ná dýpri skilningi til að geta kafað dýpra og hugsað sjálfir. Detta gengur í gegnum öll fjögur pemun og alla bókmenntakennsluna sem eitt aðalmarkmið pessa að vinna með Laxdæla sögu. Áhugi virðist vera bæði útgangspunkturinn og niðurstaðan.

Fyrsta pemað sem birtist með skýrum hætti í máli allra kennaranna var að peir litu á pað sem sitt hlutverk að vekja áhuga nemenda á námsefninu. Pær töluðu gjarnan um að kveikja áhugann og að ná nemendum með sér.

Annað pemað tengist pekkingaratriðum. Til pess að komast inn í söguna kom fram í máli kennaranna að nemendur pyrftu að ná ákveðnum grunni, í fyrsta lagi að læra að pekkja persónur og fylgja sögupræði (og pví fylgir að skilja orðfæri Íslendingasagnanna). Í öðru lagi pyrftu peir 
að öðlast skilning á siðfræðihugtökunum sem lágu til grundvallar verkefnaheftinu sem fylgdi sögunni.

Priðja pemað sem kennararnir lögðu áherslu á var pað að nemendur gætu lifað sig inn í bókmenntirnar og sett sig í spor persónanna, og sumir kennarar virtust tengja pað pví að geta tekið afstöðu til siðferðilegra álitamála. Einnig fannst peim siðfræðinálgunin styðja petta markmið.

Fjórða pemað tengist síðan hugmyndum um að brjóta heilann og kafa dýpra. Markmiðið er að nemendur öðlist dýpri skilning, dragi sínar eigin ályktanir og verði sjálfstæðir lesendur og hugsandi manneskjur.

\section{Að kveikja áhuga á bókmenntum}

Svandís kennari í Straumfjarðarskóla hefur verið kennari nokkuð lengi og hefur mikla reynslu af pví að kenna Íslendingasögurnar. Hún ber kennsluaðferð sína í rannsóknarverkefninu saman við pað pegar ákveðnar Íslendingasögur voru kenndar sérstaklega til samræmds prófs í 10. bekk: „pá var petta bara utanbókarlærdómur" en núna segir hún að áherslan sé frekar á að nemendur upplifi раð аð Íslendingasögurnar séu „skemmtilegar sögur [...] af tíma sem var hér á landi“ til pess að „tengja svolítið við ræturnar [...]“. Hún segir að upp á síðkastið hafi pannig ,skemmtanagildi“ sagnanna frekar ráðið ferðinni „,maður hefur viljað að petta sé gaman, pau hafi gaman af pessu og tengi við sögur sem eru skemmtilegar og fjalla um atburði sem eru áhugaverðir“.

Guðfinna kenndi einnig Íslendingasögurnar á pví tímabili pegar prófað var úr peim með samræmdum prófum og tekur í sama streng: „Đað var náttúrulega spurt á samræmdu prófunum bara úr smáatriðum svolítið. Pannig að við fórum náttúrulega rosalega vel í pær.“ Hún segir að núna taki hún pær allt öðruvísi fyrir og reyni frekar ,að láta krakkana njóta pess meira að lesa [...]. Við erum ekki að, endilega að kryfja hver sagði hvað við hvern og eitthvað svona heldur að skoða hana, skoða Íslendingasögurnar svona meira og [...] reyna að kveikja ást peirra á Íslendingasögunum [...].“

Í kennslunni kemur petta fram í pví að pær leggja ekki jafnmikla áherslu á alla söguna, eins og gert var fyrr, heldur á valda pætti, pað sem peim finnst mikilvægt og áhugavert, og dvelja minna við annað. Pær eru öruggar í pessum fornsagnaheimi, hafa kennt nokkrar Íslendingasögur og notað mismunandi aðferðir við pað.

Tinna kennari í Hamravíkurskóla hefur ekki mikla reynslu af pví að kenna Íslendingasögurnar en velur pá leið að lesa Laxdælu fyrir nemendur. Hún talar um mikilvægi pess að börn fái að njóta pess að hlusta á lestur. Sem dæmi um hversu áhugasöm pau eru nefnir hún hversu lítið hún parf að hafa fyrir pví að fá pau til að hlusta. „Dau eru fljót að gefa hljóð og eru tilbúin til að hlusta á söguna af pví pau vilja meira."

Eva María les einnig söguna fyrir nemendur, henni finnst pað „alveg nauðsynlegt“ til pess að „allir fái söguna“. Degar hún hefur lesið einn kafla útskýrir hún með stuttri endursögn á eftir svo allir skilji söguna. Hún tekur eftir pví að nokkrir sem eru vanvirkir í verkefnavinnunni sýna samt sögunni áhuga og taka pátt í samræðum.

Hrefna kennari í Viðvíkurskóla fær sína nemendur til að lesa heima, helst upphátt, og ræða álitamál við fjölskyldumeðlimi. Hún hlustar eftir pví hvað nemendum finnst áhugavert og reynir að dvelja við pau atriði í sögunni og dýpka pau fyrir nemendum. Hún segir að stúlkurnar í sínum bekk hafi til dæmis verið mjög uppteknar af konunum í sögunni; af Melkorku, Jórunni, Auði djúpúðgu, Guðrúnu og Dorgerði, sem hún gefi sér pá tíma til að velta fyrir sér. Hrefna hefur sjálf mikinn áhuga á Íslendingasögunum og vonast til að ástríða sín „smitist til nemendanna“. Hún bætir einnig við fróðleik til að vekja áhuga, segir nemendum til dæmis að pegar persónur í Íslendingasögunum fari til útlanda sé oft hægt að sjá pær í nýju ljósi, pannig sé til dæmis hægt að 
kynnast Kjartani og Bolla betur pegar peir fara til Noregs „og pað var einhver sem sagði eitthvað svona, Kjartan er alveg eins og mamma hans, hann er sko ekki eins og pabbi hans“. Hún segir að par sem Îslendingasögurnar séu svona fjarlægar okkur í tíma purfi jafnvel að leggja meira upp úr pví að kveikja áhuga nemendanna.

Svandís segir að pað sé mikilvægt að finna Íslendingasögunum ,farveg pannig að pær eigi erindi við krakkana okkar í dag“. Pannig purfi „,a matreiða petta rétt í byrjun“ og „ef maður [nœer] peim af stað pá finnst peim petta gaman“. Hún notar svokallaða sagnaaðferð við kennsluna. Hún felst í pví að endursegja söguna, með eigin orðum eins og hún sé að segja nemendum sögu. Hún fær pá til að lesa heima og segir að peir vilji koma undirbúnir í tíma til að „vera með á nótunum“ og pví virkar aðferðin sem eins konar upprifjun og útskýring á orðaforðanum sem er í bókinni. Henni finnst pessi aðferð virka vel fyrir sig til að ná nemendum með sér og fylgja sögunni. „Ég finn pað að ég næ krökkunum," segir hún.

Drátt fyrir ólíkar aðferðir virðast allir kennararnir leggja áherslu á að nemendur fái áhuga á lestri Laxdælu og telja að pað sé að einhverju leyti í sínu valdi að pað gerist. Guðfinna segir að pað sé „svo mikilvægt að pau fái áhuga á lestri. Mér finnst svo lítið gerast pegar krakki hefur ekki áhuga. Pá er hann bara að moka einhvern flór, og bara klára, ,er petta nóg? ““ Áhuginn er síðan grundvöllur fyrir pví að læra meira. En pað tekst ekki alltaf að ná öllum með. Баð er ábyrgð sem pær taka á sig sjálfar. Eins og Tinna segir: „Mér finnst petta mjög gaman [en] petta höfðar náttúrulega misvel til nemendanna." Hún segist útskýra mikið, stoppa og fá pá til segja sér hvað sé að gerast: „ég reyni að spyrja pau mikið bara hvað er að gerast pannig að mér finnst pau fylgja mér alveg ágætlega í pessu, eða fylgja sögunni“. Hún segir að nemendurnir hafi orðið mjög spenntir pegar Guðrún giftist Bolla og verið vissir um að Kjartan myndi drepa hann.

Dað voru alveg fastir spádómar parna, pannig að pað verður alveg spennandi að lesa af pví við erum komin að ákveðnu uppgjöri í sögunni. Og pannig að mér finnst pau alveg $[\ldots]$ pað er samt [...] ég parna nee ekki öllum. Ég veit pað, pau eru parna einstaka [sem hugsa] Íslendingasaga sama sem drepleiðinlegt.

Hrefna tekur undir petta:

Auðvitað eru alltaf einhverjir sem bara, sigla parna í gegn og petta verður bara eins og hver annar brotsjór, sko - en aðrir svona virkilega vakna, pú veist, og hafa jafnvel tekið einhver skref, pú veist, og farið eitthvað lengra, farið og nád sér í eitthvað meira efni eða [...] pú veist, pað varð einhver skilningur.

Guðfinna er á sama máli:

Já, mér finnst pað ekki vera markmiðið pegar pau eru búin að lesa Laxdælu að pau kunni hana utanbókar eða eitthvað slíkt en að pau hafi - hafi haft gaman af henni og ég held að pað sitji frekar eftir - ef að pau hafa, ef maður nær að kveikja áhugann, að pá fari pau jafnvel að kafa dýpra.

\section{Pekkingaratriði}

Dekkingaratriðin sem kennararnir lögðu áherslu á varða (i) hver er hvað í sögunni og (ii) dygðir og lesti sem fjallað er um í verkefnaheftinu.

i. Að mati kennaranna var bekking á ýmsum staðreyndum sögunnar og sögubræði forsenda pess að sagan yrði áhugaverð. Kennararnir nota allir einhverjar leiðir til pess að vera vissir um að nemendur fylgi pessum pekkingaratriðum og séu ,ekki alltaf að velta fyrir sér hver sé hvað“, eins og Guðfinna segir. Hún lagði próf fyrir nemendurna pegar pau voru komin nokkuð á veg með söguna til að pau myndu átta sig á persónum, nöfnum og ættartengslum: 
„píndi pau svona svolítið til að leggja pað á minnið“. Bæði Tinna og Eva María eru með æettartré uppi á töflu í sama tilgangi. Tinna sagði að pau hefðu orðið „,svolítið rugluð [...] pá ákvað ég bara að teikna petta upp fyrir pau“. Hún segir að pau hafi átt frekar erfitt með pað pegar Guðrún kom inn í söguna af pví að pað var ekki hægt að tengja hana strax við ættartréð. „Bara hver er petta, pessi Guðrún? Pannig að við fórum svolítið í pað. Ég bara: ,petta er bara stelpa af næsta bæ og svona [...].““

Hrefnu virtist nemandi vera að ruglast á persónum og fékk hann til að gera „portrett“ af peim, einnig að myndgera valdar senur úr bókinni. Svandís var með nokkurs konar lestrarkönnun par sem nemendur gátu flett upp í bókinni og tengt saman aftur til að rifja upp persónur og atburði og Guðfinna leyfði peim að skrifa inn í lestrarbókina: „við höfum lofað að henda pessari bók pannig að ég er ekki eyða tíma í að skrifa nema bara svona til að átta sig á ef pau purfa að rifja eitthvað upp hver er hvað“.

Dær nota pví allar einhverjar leiðir til að leggja ákveðinn pekkingargrunn. En vilja „ekki leggja áherslu á pað“ eins og Hrefna segir: „,petta er auðvitað svolítið drill svona, pú veist, hver var sonur hvers og svona du du du sem mér finnst ekki skipta höfuðmáli í kennslunni“.

Eva María segir að hún leggi „svolítið á [sig] til að pau skilji söguna, að pau skilji hvað er að gerast, pví að ef pau gera pað ekki, ef pau skilja ekki hvað er að gerast, pá getum við eiginlega gleymt pví að tala um rest“. Hún segir að pað sé erfitt að fara að tala um dygðir og lesti persónanna ef sögupráðurinn er ekki á hreinu. „En pað fer ekki allt púðrið í pað hver átti heima hvar heldur frekar hvað er að gerast, hver er að gera hvað á hlut hvers og hvers vegna. Mér finnst pau hafa nád að fara inn í söguna pannig."

ii. Til grundvallar siðfræðikennslunni (siðferðilegum orðaforða og siðferðilegum hugtökum) liggur verkefnahefti par sem áherslan er lögð á átta dygðir. Í upphafi er lögð áhersla á að skýra og skilja hvað dygð sé og hvað sé löstur en síðan eru átta dygðir og samsvarandi lestir sett í samhengi við persónur og atburði í fyrstu köflum Laxdælu.

Í samtali við alla fimm kennarana kom fram að peim fannst skilningur nemenda á dygðaorðaforðanum vera mjög takmarkaður í upphafi verkefnisins. Eins og Eva María segir: „pau höfðu aldrei heyrt pessi orð nefnd, sko, fannst peim allavega pegar við byrjuðum með pessi hugtök “. Henni fannst mikilvægt að fara hægt af stað og taka langan tíma í að vinna með hugtökin og skilning á peim áður en pau byrjuðu að lesa söguna. Hrefna tekur undir petta og segir að orð eins og örleti, gjafmildi, hófsemi hafi ekki verið í virka orðaforðanum peirra ,peim dagsdaglega“.

Tinna og Guðfinna eru á sama máli. Guðfinna segir að pau hafi ekki pekkt orðin sáttfýsi eða sanngirni, og orðið prautseigja hafi líka verið peim framandi í upphafi en síðan hafi pau verið farin að átta sig á merkingu pess pegar leið á verkefnið. Dær notuðu báðar góðan tíma í upphafi til að fara vel ofan í dygðirnar áður en nemendur byrjuðu að lesa söguna. Aftast 1 verkefnaheftinu er langur listi með orðum yfir dygðir sem Guðfinna notaði pegar hún bað nemendur að velja sér dygðir sem peim pættu eftirsóknarverðar, ræða um pær og útskýra valið hver fyrir öðrum. Með pessu verkefni fengu nemendur tækifæri til að heyra mismunandi rökstuðning fyrir kostum og göllum dygða og lasta og tengja dygðirnar og lestina við sjálfa sig og sessunauta sína.

Svandís segir mikilvægt að „,vera vakandi“ yfir pví að nemendur auki við orðaforða sinn og segir að „ein leiðin [sé] að vera með markvissa hugtaka- og orðaforðakennslu pví pað komi alltaf net í kringum hana“. Hún hefur pær átta dygðir sem mesta áherslan er lögd á í verkefnaheftinu uppi á töflu og nemendur tengja pær við persónur í Laxdælu og við sitt eigið líf. 
Allar segjast pær fara svipaða leið í upphafi, taka tíma í að útskýra og vinna með dygðir, skilgreina pær og skoða persónur Laxdælu með dygðahugtökin að leiðarljósi. Síðan tengja pær dygðirnar við söguna eftir pví sem kaflarnir eru lesnir og taka fyrir ýmis siðferðileg álitamál í sögunni.

Tinna lýsir pví hvernig staðan hafi verið um miðbik kennslunnar. Hún nefnir orð eins og prautseigju og sáttfýsi sem hafi bæst við orðaforða barnanna síðan verkefnið hófst. Eftir að pau byrjuðu að vinna með dygðirnar og ,spá og spögulera mikið í peim, [heyrir hún] pau stundum tala, tala sín á milli“ um dygðir. Hún nefnir svo dæmi af strák ,sem fór í smá fýlu á leiðinni út úr tíma“ hjá henni. „Ég sagði bara [...], heyrðu [...] pað verður ekki meira úr pessu', eitthvað svona bara [...],já ég er sáttfús maður,, svaraði hann.“

Eva María segir að nemendum finnist peir vera „fornfálegir“ í tali pegar peir noti orðin en séu farnir að nota pau bæði í gríni og alvöru. Hún hafi t.d. heyrt pá nota orðið fifldirfska sem peim finnist fyndið. Detta kom einnig fram hjá öðrum kennurum, p.e. að nemendum fannst siðferðilegu hugtökin jafnvel framandlegri en orðfæri Íslendingasögunnar. Eva María lýsir pví síðan hvernig dygðaorðaforðinn hafi smitast út fyrir íslenskukennsluna. Við gerð bekkjarsáttmála hjá nemendum í einum bekknum sem hún kennir komu fyrir orð eins og réttsýni, prautseigja, heiðarleiki, friðsemd, hjálpsemi og gleði. Hún segir einnig frá verkefni í samfélagsfræði sem fólst í pví að taka ævisöguviðtöl við fólk á elliheimili. Einn drengurinn tók viðtal við gamla konu sem sagði honum frá pví að hún hefði purft að ganga pó nokkra vegalengd í skólann í öllum veðrum og stundum getað húkkað sér far með mjólkurbílnum. Kennarinn hlustaði á nemandann lýsa pví yfir eftir viðtalið við konuna að hún hefði greinilega purft að sýna „mikla prautseigju“.

Nemendurnir purftu fyrst að öðlast skilning á hugtökum og orðaforða, skilgreina og jafnvel læra utan að hvað pau pýddu. Síðan purftu peir að máta sig við pau og læra hvernig og hvenær væri hægt að nota pau, sem peir voru byrjaðir að gera; í texta, samtali sín á milli og í samtali við eldra fólk.

\section{Að setja sig í spor persóna}

Eins og áður sagði les Tinna Laxdæla sögu fyrir nemendur: „peim finnst voða gaman að hlusta bara á sögur“. Dótt Tinna tali ekki um pað pá felst í pví að nemendur njóti pess að hlusta ósk um að peir lifi sig inn í söguna, sjái hlutina fyrir sér og setji sig í spor sögupersóna. Hún hefur lesið ævisögur fyrir nemendur, til dæmis í tengslum við samfélagsfræði, til að dýpka fyrir peim skilning á aðstæðum fólks á fyrri tímum og sampætta námsgreinar.

Vettvangsathugun hjá Tinnu styður pá staðhæfingu að hún reyni að fá nemendur til að setja sig í spor persónanna. Hún tekur fyrir atburðinn pegar Kjartan hefnir sín á Bolla eftir stuldinn á sverðinu og motrinum, og lokar Laugamenn inni svo peir komast ekki út til að gera parfir sínar.

Kennari spyr: „Af hverju var ekki skynsamlegt hjá Kjartani að dreita Laugamenn inni? Hvað hefðuð pið gert?“

Einn nemandinn, strákur, svarar: „leita sannana áđur“.

Kennari er sammála pví að pað hefði verið skynsamlegra. Nú sé hins vegar „fullur fjandskapur milli Laugamanna og Hjarðhyltinga“, eins og segi í bókinni.

Tinna segist spyrja nemendur mikið af hverju persónur geri petta eða hitt til pess að fá pá til að skilja hvaða tilfinningar liggja að baki. Hún segir: „ef maður grefur djúpt í söguna, pá finnur maður tilfinningar og fer að spyrja: af hverju er hann að gera petta?“

Eva María sagði að nemendurnir hefðu lifað sig mjög mikið inn í söguna: „héldu með sínu fólki og mynduðu sér strax skoðanir á sögupersónunum“. Hún ber saman kennslu Hrafnkels sögu 
og Laxdælu og segir að nemendurnir hafi ekki náð að „samsama sig persónum jafnmikið“ í Hrafnkels sögu. „Рað var peim meira svona framandi [...] pau áttu kannski erfiðara með að setja sig einhvern veginn í spor sögupersóna." Hún telur að siðfræðivinkillinn og áherslan á dygðir og lesti sögupersónanna geri pað að verkum að nemendur eigi auðveldara með að setja sig í spor persónanna og hafi meiri áhuga á pví. Henni finnst petta einnig hjálpa til við að peir „hugsi aðeins dýpra" um hvað liggur að baki gjörðum persóna, hverjar afleiðingar pessara gjörða eru og hvort pví fylgi jafnvel eftirsjá sem sé í „fullkomnu samhengi við söguna og sögupráđinn“.

Ég held að til pess að skilja sögur, að ég tali nú ekki um til pess að skilja sögur um fólk, pá parftu einhvern veginn að geta sett pig í spor peirra og petta hjálpar par til.

Guðfinna vinnur einnig markvisst í pví að fá nemendur til pess að lifa sig inn í hlutverk, par sem peir takast á við valin efni úr sögunni eða taka fyrir ákveðnar persónur til að fjalla um dygðir peirra eða lesti. Í nótum úr vettvangsathugun kemur fram að strákar völdu að taka fyrir dygðina hugrekki með pví að sýna sundkaffæringar Kjartans og Ólafs konungs úti í Noregi með tilheyrandi stimpingum, hnoði og leikrænum tilprifum sem enduðu með vináttukossi við mikla kátínu bekkjarfélaga og kennara (pað var ef til vill kærkomin tilbreyting að fá að slást í tíma). Guðfinna segir að nemendur hafi einnig heillast af Melkorku. „Deim fannst hún svona spennandi týpa, mállaus konungsdóttir“ og sýndi svo mikla , prautseigju og lítillati“ að vera ekkert „,að básúna pví að hún væri konungsdóttir“. „, Рað eru einhverjir töfrar yfir henni, pau tengja hana við pennan bókaheim sem pau eru spennt fyrir, töfraheim." Guðfinna brýtur upp kennsluna með gerð leikpátta og stuttmynda til að hún verði ekki of einhæf, annars segir hún að pað sé hætta á að nemendur festist bara í pví að „,svara spurningum úr sögunni, bara stöðugt einhver leitarlestur og pau eru kannski ekki einu sinni að lesa söguna, vita ekkert og gengur ekki út á að skilja eða að njóta pess að lesa söguna heldur gengur út á að finna - svörin.“"

Hrefna leggur einnig áherslu á að pað sé ekki pað sama að lesa og að lesa. Hún lýsir pví hvernig hún vann markvisst í pví að fá nemendur til að setja sig í spor persónanna. Degar hún ræddi um kaup Höskuldar á ambáttinni Melkorku fann hún að nemendur höfðu litlar skoðanir á málinu, en pegar hún lét pá leika mismunandi hlutverk í nokkurs konar leikpætti (par sem Höskuldur t.d. skoðaði hendur Melkorku til að vita hvort hún gæti spunnið ull og kíkti upp í hana til að sjá hversu vel tennt hún væri) knúði hún pá á vissan hátt til pess að upplifa á eigin skinni hvernig væri að vera viðkomandi persóna.

Pannig að petta er bara eins og alltaf, pað parf bara að svona hrökkva í gang [...] Darna lásu pær bara samviskusamlega heima, pú veist, pær bara lásu texta, en pær voru ekkert að [rannsakandi: ekkert að hugsa?] pá er pað bara svona ,hei ég er búin að lesa heima‘ en núna finnst mér petta bara, miklu meira, sko, sterkari skoðanir.

Hún segir að bókmenntakennslan snúist um að fá nemendur til „að tengja, tengja við peirra samtíma og svona setja sig í spor".

\section{Ad brjóta heilann}

Ef til vill er ekki að undra pótt kennarar komist ekki upp fleiri prep en pau prjú sem pegar hefur verið lýst; að ná utan um persónur og atburðarás, flókinn orðaforða, innleiða ný hugtök og kveikja áhuga barna á gamalli sögu um fyrstu kynslóðirnar eftir landnám Íslands. Er ekki nóg að geta sett sig í spor persónanna og nád sögupræðinum?

Dað er pó eitt prep eftir, sem er ef til vill pað tímafrekasta og erfiðasta, en pað er að brjóta heilann um hlutina og hugsa sjálf. Рað að brjóta heilann miðar að pví að fá nemendur til að hugsa sjálfir um söguna og draga sínar eigin ályktanir. Ef til vill hefur betta alltaf verið markmið bókmenntakennara og bókmenntakennslu, að nemendur njóti pess að lesa á eigin forsendum og dragi sínar eigin ályktanir af efninu, pótt ekki sé alltaf skýrt hvernig pað sé gert. Kennararnir sem tóku pátt í pessu verkefni hafa hingað til unnið með pessa pætti að einhverju marki eða að minnsta kosti viljað komast pangað. 
Verkefnaheftið inniheldur skilgreiningar á dygðum og löstum, spurningar og hugmyndir um pað hvernig má tengja Laxdælu og siðfræðikennslu. Flest verkefnin miða að pví að skoða sögupersónur og atburði út frá breytni og gjörðum með pað að markmiði að hjálpa bæði nemendum og kennurum markvisst og skipulega við að brjóta heilann um hlutina út frá dygðum og löstum. Mörg verkefnin kalla á einhvers konar samanburð: Í fyrsta lagi samanburð á sögupersónum. Í öðru lagi samanburð og tengsl við nemandann sjálfan og veruleika hans. Í priðja lagi samanburð við aðrar bókmenntir, kvikmyndir, tónlist og dægurmenningu. Í fjórða lagi samanburð á nútímanum og Laxdælutímanum, samfélagsgerð nú og pá (stjórnmál samtímans/fréttir). Í fimmta lagi samanburð við heiminn í stærra samhengi.

Að sögn kennaranna eru pessi skref pau hin sömu og pær sjálfar vilja að nemendur taki í gegnum bókmenntakennsluna. Fyrst purfa peir að lifa sig inn í söguna, sjá fyrir sér og setja sig inn í aðstæður og í spor persónanna. Peir purfa að „tengja“, eins og Hrefna segir, „,əð tengja við textann“ pannig að hann sé ekki „,bara orð á prenti“. Deir purfa einnig að pekkja siðfræðihugtökin og sögupráðinn. Síðan virðist vera hægt að brjóta heilann.

Hrefna leggur mikið á sig til að fá nemendur til að setja sig í spor sögupersóna og gerir meira en pað. Hún segir til dæmis: „pú ert [Melkorka] [...] og pú ert stödd í pessu“. Pannig setur hún ekki bara nemandann í spor sögupersóna heldur tekur næsta skref og biður hann að bera saman hlutskipti sitt og hlutskipti hennar. Dað er ekki nóg að vera orðin Melkorka heldur parf að fjarlægja sig textanum aftur og skoða hver sé munurinn á mér og Melkorku. Hver er munurinn á heiminum pá og nú? Hrefna segir að pað að setja sig í spor Melkorku hafi leitt bekkinn út í „samræður um nútímaprælahald og - mansal og [...] barnaprælkun“ sem hún hafði áður tekið fyrir í kennslubók í tengslum við lífsleikni. Pannig eru nemendur farnir að bera saman sinn veruleika og „,veruleika“ bókmenntapersónunnar Melkorku sem finnst 1 Íslendingasögu; skoða muninn á aðstæðum Melkorku og aðstæðum í nútímasamfélagi, í heiminum í dag. Hún segir að pað sé mikilvægt að nemendur tengi söguna við samtíma sinn til að hafa skoðanir á hlutunum en hún víkkar síðan sjálf út tenginguna, tengir pau við allan heiminn. Lykilatriðið virðist vera að bera saman.

Tinna gerir slíkt hið sama. Hún fær nemendur til að tengja dygðirnar við sjálfa sig með pví að láta pá skrifa dagbókarfærslu um kærleikann út frá peim sem peim pykir vænt um og kallar pannig fram samanburð á kærleika eins og hann birtist í sögunni annars vegar og eins og hann birtist í veruleika nemandans í nútímanum hins vegar. Detta tengist ef til vill verkefnaheftinu, par er nemandanum bent á að nefna persónur sem honum pykir vænt um og hann beðinn að útskýra af hverju. Tinna tengir petta kennsluaðferðum sínum og pví sem nemendur eru vanir að gera hjá henni, að skrifa dagbækur til að æfa ritun.

Guðfinna segist alveg vera hætt að „,spyrja pau í hvaða sýslu gerðist petta“ eða út í „einhver svona pekkingaratriði“. Nú segist hún nota söguna frekar sem „,ææmisögu“. „Nú vill maður bara að pau geti lagt út frá, dregið ályktanir og lesið milli línanna." Hún notar mikið samræðuaðferðir við kennslu sína par sem pau sitja saman í hring, lesa og rifja upp kaflann og velta síðan fyrir sér álitamálum. „Sko, ég er miklu minna að láta pau skrifa, meira að láta pau tala og spjalla [...] Um leið og pau eru komin í hring, pá eru pau komin í pann gírinn, en ég tek yfirleitt ekki umræður par sem pau sitja í sínum sætum.“ Hún segir að pau hafi oft gleymt sér í spjallinu „við vorum að taka allan fjandann inn í petta, sérstaklega kvenréttindi og jafnrétti og réttindi barna og umræðurnar fóru út um allt [...]" Hún segir að nemendum hafi verið mjög umhugað um barn Geirmundar og Duríðar sem Duríður skipti út fyrir sverðið Fótbít. „Við lásum um réttindi barna og Barnasáttmálann.“

Darna er Guðfinna að tengja söguna veruleika nemenda, samfélagsgerð samtímans, lögum og reglum, og benda á muninn á heiminum í gamla daga og heiminum í dag. Hún virðist einnig gefa sér tíma til að hugsa með nemendum en segir að pað erfiðasta fyrir hana sjálfa hafi verið að læra að halda aftur af sér og tala ekki of mikið sjálf. Leyfa peim að tala. Eitt sinn kom upp umræða um hvort punglyndi teldist vera löstur. Um petta ræddu pau mikið út frá pví að hvaða marki fólk 
stjórnaði sjálft dygðum sínum og löstum. Nemendunum fannst punglyndi frekar vera sjúkdómur „og við vorum eiginlega búin að sammælast um pað“.

Bæði Tinna og Hrefna nefna раð аð missa ekki af umræðutækifærunum. Hrefna nefnir sem dæmi að nemendur geti oft verið mjög dómharðir um sterkar kvenpersónur „eins og Hallgerður og Guðrún, pær eru oft dæmdar mjög hart“. Dá sé mikilvægt að taka umræðuna, ,ekki að leyfa hlutunum bara að koma og vera“ heldur staldra við og „,reyna að skoða aðstæður og ástæður“ og mismunandi sjónarmið. Tinna leitast við að komast að samkomulagi um rétta svarið. Markmiðið er ekki endilega að kryfja mismunandi sjónarmið og fá ólík svör heldur leita að svarinu saman. Ef pau finna ekki svarið sjálf pá segir hún að pau hafi tilhneigingu til að leita til hennar og spyrja „er petta rétt, á ég að breyta? [...] en pau mega samt hafa sínar skoðanir“ ef pau eru ósammála. „Ég hef reynt að [hafa pað pannig að] ef pér finnst petta, pá er pað í lagi.“

Eva María hefur einnig kennt samfélagsgreinar sem snúast mikið um ýmsar vangaveltur og samræður, par sem hún segir að nemendur „máti sig í inn í alls konar aðstæður í samfélaginu“. Hún segir að sér finnist skemmtilegt „petta samtal“ sem hún á við nemendur og pað sé af svipuðum toga hér og hún sé vön. „Maður reynir að vera svolítið hlutlaus pótt maður sé pað ekki, gefa peim rými til að rökstyðja eigin skoðanir og finna pær út sjálf." Hún segir að pað geti pó reynst erfitt að meta frammistöðu nemenda eða verkefni: „,pú veist, hvað er kærleikur, af pví аð pað er ekkert já eða nei, rétt eða rangt, kannski beint. Раð er erfitt að segja bara petta er rangt og petta er rétt pegar nemendur eru svona að velta fyrir sér. Ваð hefur kannski reynst best að ræða pað nánar." Hún lýsir pví svo að pegar nemendur taka mjög harða afstöðu eða tjá öfgafullar skoðanir - eru jafnvel að reyna að ögra, sem leiðir gjarnan til pess að hinir nemendurnir taka mjög afdráttarlausa afstöðu á móti - pá skapist ,einhverjar svona rökræður“ en yfirleitt leysist pær innan veggja stofunnar, „ég reyni að beina í farveg en pau sjá oftast um að greiða úr pví sjálf“.

Svandís segir að siðfræðiumræðan geti verið krefjandi: „Maður parf að vanda sig af pví að við erum ekkert vön pví að vera mikið í pessu í skólanum." Hún segir að sér hafi kannski ekki fundist nemendurnir sem hópur „komin á pennan stað að vera tilbúin í djúpar samræður“ og sér hafi fundist erfitt að fá pau í einlægar pælingar: „Рað eru ekki nógu margir sem ráđa við svona alvöru pælingar.“ Hún reyndi pað en „,pað fer svolítið út í hvað mér finnst og petta er náttúrulega af pví að ég er íslenskukennari, ég er að kenna peim málfræði sem er nú oftast svolítið klippt og skorin“. Hún segir samt að „,pau [séu] alveg að velta fyrir sér ýmsum álitamálum“ og að skrifleg verkefni hafi komið vel út hjá sumum einstaklingum sem ekki hafi farið mikið fyrir í kennslustundunum sjálfum, svo sé hægt að nálgast námsefnið á mismunandi forsendum og pví í lagi að pau séu ekki öll á sama stað. Eins og hún segir: „maður hefur auðvitað alltaf, í bókmenntakennslu, verið að vinna með siðfræði, en kannski ekki á eins meðvitaðan hátt“ og pess vegna finnst henni hugtakakennslan hjálpa til við að gera hana markvissari: „,pað er rosa flott að vera með átta hugtök og petta eru hugtökin sem við æfum okkur að ná tökum á og pað er bara frábært“.

Sem lokaverkefni fékk Svandís nemendur til að bæði rökstyðja hver væri aðalpersóna Laxdælu en einnig hvaða dygð væri eftirsóknarverðust í sögunni og hvaða persóna byggi yfir henni. Deir fengu sem sagt tvö verkefni, annað um bókmenntir og hitt um siðfræði, sem pó tvinnuðust saman og kröfðust pess að nemendur leituðu sjálfir að svörunum og drægju sínar eigin ályktanir af sögunni: Yrðu sjálfstæðir lesendur og hugsandi manneskjur.

\section{Umræða og lokaorð}

Í greininni er leitast við að svara eftirfarandi spurningum:

i. Hvernig pykir kennurum pað fara saman að kenna um siðferði og að kenna bókmenntir eins og Laxdæla sögu?

ii. Hvaða tilgang sjá kennarar með pví að kenna Laxdæla sögu? 
Í viðtölum við kennarana kemur fram hvernig peir setja siðfræðiverkefnið í samhengi við hugmyndir sínar um tilgang pess að kenna Íslendingasöguna Laxdælu. Í stórum dráttum má segja að kennarar fari upp fjögur prep til pess að tengja nemendur sögunni og pau miða öll að pví að njóta bókmenntanna. Í öllum viðtölunum birtist sú skoðun kennaranna að tilgangur bókmenntalesturs sé að njóta hans. Petta kemur fram í áherslu kennaranna á mikilvægi pess аð nemendum finnist gaman að lesa og gott að hlusta, fái áhuga á lestri bókmennta og hafi ástríðu fyrir slíkum lestri. Í raun kemur fram viðhorf í pá veru að bókmenntir eigi að vera bæði mannbætandi og proskandi og hafi listrænt gildi í sjálfu sér.

Рað sem liggur að baki pessari sterku áherslu á áhuga á bókmenntum er ef til vill hægt að tengja við pað sem Schiller (2006) sagði um listina að lifa og hvernig hún tengist frelsinu til að proskast til fulls. Hér er á ferðinni einhvers konar leikur sem er leiddur af kennara sem vill kenna nemendum bókmenntaverk af ástríðu í stað pess að vera „bara að moka flór“, vill að peir gefi sig ímyndunaraflinu á vald og sjái út fyrir sinn veruleika og inn í heim möguleikanna. Kennararnir sem rætt var við reyndu pannig að leggja rækt við mennskuna og tilfinningarnar ekki síður en að miðla pekkingu.

Áhuginn er fyrsta prepið og útgangspunkturinn. Markmiðið er að nemendur komist inn í söguna, setji sig í spor sögupersóna og nái að lokum betri skilningi til að geta kafað dýpra og hugsað sjálfir. Dessa ábyrgð taka kennararnir á sig, pað er í peirra valdi að ná nemendunum með sér, kveikja áhugann, fá bá til að fylgja sér og sögunni og finnast petta skemmtilegt. Petta er samt sem ádur ekki innihaldslaus skemmtun eða afpreying. Î raun er petta menntandi tími og menntunin er sannarlega ekki fyrirhafnarlaus. Til pess að komast inn 1 Íslendingasögur parf að setja sig inn í ýmis pekkingaratriði auk pess að fylgja sögupræði og persónum og pví fór hluti tímans bæði í раð аð fræða nemendur um staðreyndir um pann heim sem sögurnar eru sprottnar úr og ýmsar orðskýringar og annað sem parf til að peir skilji sögurnar - auk peirra siðferðilegu hugtaka sem bættust við. Dessi atriði voru nauðsynleg til að fjalla um söguna en voru kennurunum einungis annað prepið í átt að dýpri skilningi. Markmiðið var að öðlast skilning á fólkinu sem sögurnar segja frá, að setja sig í spor fólks sem lifði við önnur kjör og aðra siði en við.

Nussbaum (2010) talaði um að ímyndunaraflið væri grundvöllur pess að geta sett sig í spor annarra og að listir gegndu mikilvægu hlutverki við að koma í veg fyrir pröngsýni og fordóma og að kenna börnum samhygð og umburðarlyndi fyrir pví sem væri framandi. Hún sagði að með pví að sjá heiminn með augum annarra lærðum við að lifa með öðrum manneskjum í heiminum af virðingu og innsýn. Petta viðhorf kemur sterkt fram hjá kennurunum. Deir leggja mikið á sig til að nemendur lifi sig inn í söguna, setja pá í hlutverk og fá pá til að velta fyrir sér stöðu persónanna í pví samfélagi sem sagan lýsir. Detta er priðja prepið og virtist vera mikilvægt bæði til að tengjast sögunni og til að geta tekið afstöðu til siðferðilegra álitamála. Einnig fannst peim siðfræðinálgunin hjálpa til við petta markmið.

Fjórða prepið tengist síðan hugmyndum um að brjóta heilann og kafa dýpra. Dar kemur til sögunnar verkefnaheftið sem tengir Laxdæla sögu og siðfræði en einnig rík tilhneiging kvennanna fimm sem rætt var við til að fara út fyrir heftið en gera pó svipaða hluti og par var að finna; pað sem pær voru vanar að gera í bókmenntakennslu. Рað að brjóta heilann kemur fram í nokkrum páttum sem snúa að pví að tengja nemendur með einum eða öðrum hætti við efniviðinn, t.d. fá pá til að bera saman persónueinkenni og dygðir og lesti persóna í sögunni, tengja söguna við sjálfa sig og sinn veruleika, tengja nútímann við heim genginna kynslóða og bókmenntaheiminn við veruleikann, skoða hlutina í litlu samhengi og í stóru. Баð er freistandi að setja pennan samanburð og tengingar upp í nokkurs konar stig eftir aldri og proska en pegar á allt er litið er markmiðið á endanum að öðlast dýpri skilning. Svarið við seinni rannsóknarspurningunni um tilgang pess að kenna bókmenntir eins og Laxdæla sögu er pví í stuttu máli pað að kennararnir litu svo á að bókmenntirnar hjálpuðu nemendum að setja sig í spor annarra, draga sínar eigin ályktanir og verða sjálfstæðir lesendur og hugsandi manneskjur, til viðbótar við pað að setja sig inn í pekkingaratriði Íslendingasögu og njóta pess að lesa hana. 
Detta tónar ágætlega við niðurstöður úr rannsókn Kristjáns Jóhanns Jónssonar og Ásgríms Angantýssonar (2018) á íslenskukennslu í grunnskólum og framhaldsskólum par sem kom fram að kennarar töldu að menntunar- og menningarlegt gildi bókmenntakennslu væri einkum prennt: að öðlast „innsýn í mannlíf og samúð með öðru fólki“, kynna menningararfinn fyrir nemendum og lesa í merkinguna ,á milli línanna“ (Kristján Jóhann Jónsson og Ásgrímur Angantýsson, 2018, bls. 118).

Hvað viðkemur hinni rannsóknarspurningunni, peirri fyrri, pá var athyglisvert hvað siðferðinálgunin rímaði vel við sýn kennaranna á bókmenntakennslu. Samkvæmt kennurunum hjálpaði skipulögð tenging við siðfræði og pað að skoða persónur og gjörðir út frá sjónarhorni dygðanna nemendum að setja sig í spor persónanna og dýpkaði fyrir peim söguna. Pannig túlkuðu peir og skildu söguna, settu hana í samhengi við sjálfa sig og heiminn og í besta falli fékk siðfræðikennslan í bland við bókmenntasýn kennaranna pá til að njóta sögunnar og draga sínar eigin ályktanir af henni. Eins og Guðfinna sagði: „Ég hefði ekki viljað gera petta öðruvísi $[\ldots]$ og ég finn að ég hef náð til peirra með söguna [...]“”

Að lokum má pví segja að markviss umfjöllun um siðferðileg hugtök og samræða um siðferðileg efni geti, að mati kennaranna sem tóku pátt í verkefninu, bætt pekkingu unglinga á siðfræði, aukið áhuga peirra á bókmenntum og hjálpað peim að skilja bókmenntatexta.

\section{Teaching ethics through literature}

The study reported on in this paper is part of a larger research project on moral education through literature. It focuses on how reading a great work of literature offers ample opportunities to discuss and reflect on the complexity of moral life and human association and how such reflection can simultaneously improve students' understanding of concepts and ideas necessary for ethical reasoning, spark interest in literature and assist them in better understanding literary texts.

The focus of this paper is on the insights and work experiences of five teachers of Icelandic literature in grade 9 and 10 in upper elementary school who teach a shortened version of Laxdæla Saga, with special emphasis on ethical concepts and ethical contemplations related to the Saga. The research aims to answer two main questions:

I. From the teachers' point of view, how well does teaching ethics go together with the teaching of a literary work, such as Laxdæla Saga?

II. How do teachers view the purpose of teaching a work of literature such as Laxdæla Saga?

These questions are answered by using qualitative research performed in three elementary schools in Iceland. The data collection involved 10 semi-structured interviews with five teachers and observational studies which took place in their classes.

The research data was analysed and categorised, with meticulous coding to begin with and later theme-based coding. All the teachers who participated in the research were women who taught Icelandic studies in 9th and 10th grade. They were between 30 and 60 years of age, all educated in Icelandic studies but with different levels of teaching experience, from two to three years to over thirty years.

In the semi-structured interviews, the teachers shared their experience of using supplementary materials and an approach to the saga that emphasised the use of ethical 
concepts and vocabulary. In general, the teachers move through four steps to connect the students to the saga which all have to do with the students enjoying the work. From what they say about these four steps a view emerges to the effect that works of literature have an intrinsic value and studying them aims at human betterment.

The first step is to spark interest. This is revealed in the teachers' remarks on how important it is that students enjoy reading and like listening, gain interest in and have a passion for reading literature.

The second step is knowledge acquisition. The teachers all maintained that to dive deep into the saga the students must acquire certain basic knowledge; know who the main characters were, be able to follow the storyline and understand the fundamental ethical concepts included in the supplementary material provided by the research team.

The third step the teachers emphasised was the importance of students being able to fully submerge themselves into the saga and step into the characters' shoes. The teachers were also of the opinion that the ethics-based approach helped in that regard.

The fourth step relates to thinking and digging deeper. This is emphasised in the supplementary material which contains exercises and assignments that invite students to ponder open and difficult questions. All the teachers emphasised the importance of getting their students to think and dig deep and this was intertwined with their, apparently, traditional approach to the teaching of literature. Contemplating deeply - emerges in several aspects which revolve around connecting the students with the teaching material, in one way or another, for example by encouraging them to compare characteristics, virtues, and vices, to relate the material to themselves and their own reality, link their own present with by-gone eras and the world of literature with reality, to look at things in a small context and from a broad, whole world perspective. The aim is to gain a deeper understanding, draw their own conclusions, become independent readers and reasoning and thinking human beings.

According to the teachers, the association with ethics and looking at characters and deeds from the perspective of virtue ethics enabled the students to step into the characters' shoes and deepened their understanding of the saga. In that way, the students became literate in the saga, it was transferred to their own world context and helped them to enjoy the saga and reach their own conclusions regarding its content. In conclusion, it is fair to say that a discussion of ethical concepts and an interchange of ideas on ethical matters can, according to the participating teachers, make teenagers more interested in literature and help them to better understand literary texts.

Key words: Laxdæla Saga, The Saga of the People of Laxárdalur, teaching literature to teenagers, moral education, moral vocabulary, moral virtues, teaching democracy.

\section{Um höfundinn}

Dóra Björg Sigurðardóttir (thorsi@hi.is) er doktorsnemi við Menntavísindasvið Háskóla Íslands. Hún hefur fjallað um lýðræði og heimspekileg skrif kvenna á fyrri öldum.

\footnotetext{
About the author

Póra Björg Sigurðardóttir (thorsi@hi.is) is a PhD student at the School of Education, University of Iceland. Her publications include work on democracy and female philosophers of the past.
} 
Dessi grein er hluti af rannsóknarverkefni sem var unnið með styrk úr Rannsóknarsjóði Íslands (nr. 163230-051) og pakka ég sjóðnum fyrir stuðninginn. Ég pakka samstarfsfólki mínu í rannsóknarverkefninu, Atla Harðarsyni, Ólafi Páli Jónssyni, Róberti Jack og Sigrúnu Sif Jóelsdóttur, fyrir samvinnuna og gagnlegar umræður um efnið. Kennurum og starfsfólki skólanna pakka ég einnig ánægjulegt samstarf. Loks vil ég pakka ritrýnum fyrir hjálplegar athugasemdir.

\section{Heimildir}

Arthúr Björgvin Bollason. (2010). Lifsleikni Njálu - Siðfraðileg umhugsunarefni fyrir ungt fólk. Kópavogur: Skólavörubúðin.

Atli Harðarson. (2011). Húmanisminn, upplýsingin og íslenska stúdentsprófið. Skírnir, 185(1), 123-144.

Atli Harðarson. (2018). Ógæfa Bolla Dorleikssonar: Hugleiðing um hvernig Laxdæla saga leggur til spurningar fyrir lesanda sinn en svarar peim ekki. Netla - Veftímarit um uppeldi og menntun. Sérrit 2018 - Bókmenntir, listir og grunnpattir menntunar. Menntavísindasvið Háskóla Íslands. Sótt af http://netla.hi.is/serrit/2018/ bokmenntir_listir_menntun/02.pdf

Atli Harðarson, Ólafur Páll Jónsson, Róbert Jack, Sigrún Sif Jóelsdóttir og Póra Björg Sigurðardóttir. (2018). Laxdæla saga og siðferðilegt uppeldi í skólum. Netla - Veftímarit um uppeldi og menntun. Sérrit $2018-$ Bókmenntir, listir og grunnpattir menntunar. Menntavísindasvið Háskóila Íslands. Sótt af http://netla.hi.is/ serrit/2018/bokmenntir_listir_menntun/01.pdf

Brynhildur Dórarinsdóttir. (2002). Drög að kennsluleiðbeiningum með Njálu fyrir 5.-8. bekk grunnskóla. Sótt af https://www.forlagid.is/nemendur/grunnskolar/Njala_leidbeiningar.pdf

Charmaz, K. (2014). Constructing grounded theory (2. útgáfa). London: Sage.

Creswell, J.W. og Poth, C. N. (2018). Qualitative inquiry and research design. Choosing among five approaches (4. útgáfa). California: Sage.

Dagný Kristjánsdóttir. (2010). Öldin öfgafulla, Bókmenntasaga tuttugustu aldarinnar. Reykjavík: Bjartur.

Du Bois, W. E. B. (2015). The souls of black folk. New Haven, CT:Yale University Press.

Gísla saga (endursögn Ragnars Inga Aðalsteinssonar). (2017). Kópavogur: Menntamálastofnun.

Greene, M. (1973). Teacher as stranger: Educational philosophy for the modern age. Belmont, CA: Wadsworth Publishing Company.

Kristján Jóhann Jónsson. (2016). Lífið og dauðinn, og önnur viðfangsefni bókmenntakennslu. Tímarit Máls og menningar, 77(4), 65-78.

Kristján Jóhann Jónsson og Ásgrímur Angantýsson (ritstjórar). (2018). Íslenska í grunnskólum og framhaldsskólum. Reykjavík: Háskólaútgáfan.

Laxdala saga (endursögn Gunnars Karlssonar). (2017). Kópavogur: Menntamálastofnun.

Lög um grunnskóla nr. 91/2008.

Mennta- og menningarmálaráđuneytið. (2015). Aðalnámskrá framhaldsskóla:Almennur hluti 2011 (2. útg. 2015). Reykjavík: Höfundur.

Mennta- og menningarmálaráđuneytið. (2016). Aðalnámskrá grunnskóla: Almennur hluti 2011 og greinasvið 2013 (3. útg. 2016). Reykjavík: Höfundur.

Nussbaum, M. C. (1997). Cultivating humanity: A classical defense of reform in liberal education. Cambridge, MA: Harvard University Press.

Nussbaum, M. C. (2010). Not for profit:Why democracy needs the humanities. Princeton: Princeton University Press.

Ólafur Páll Jónsson. (2018). Laxdæla sem fóður fyrir gagnrýna hugsun. Netla-Veftímarit um uppeldi og menntun. Sérrit 2018 - Bókmenntir, listir og grunnpettir menntunar. Menntavísindasvið Háskóila Íslands. Sótt af http:// netla.hi.is/serrit/2018/bokmenntir_listir_menntun/06.pdf 
Róbert Jack. (2018a). Dygðir, siðferði og siðferðisproski: Að nota Íslendingasögur til mannkostamenntunar. Netla - Veftímarit um uppeldi og menntun. Sérrit 2018 - Bókmenntir, listir og grunnpattir menntunar. Menntavísindasvið Háskóila Íslands. Sótt af http://netla.hi.is/serrit/2018/bokmenntir_listir_menntun/09.pdf

Róbert Jack. (2018b). Dygðirnar í Laxdæla sögu: Efniviður fyrir mannkostamenntun. Netla - Veftímarit um uppeldi og menntun. Sérrit 2018 - Bókmenntir, listir og grunnpattir menntunar. Menntavísindasvið Háskóila Íslands. Sótt af http://netla.hi.is/serrit/2018/bokmenntir_listir_menntun/10.pdf

Róbert Jack. (2018c). Laxdœla saga: Dygðakennsla. Sótt af https://klb.mms.is/klb/laxdaela/dyga-kennsla-robert-jack/

Schiller, F. (2006). Um fagurfreðilegt uppeldi mannsins (Arthúr Björgvin Bollason og Pröstur Ásmundsson pýddu). Reykjavík: Hið íslenzka bókmenntafélag.

Sigurður Kristinsson. (2013). Siðfræði rannsókna og siðanefndir. Í Sigríður Halldórsdóttir (ritstjóri), Handbók i aðferðafraði rannsókna (bls. 71-88). Akureyri: Háskólinn á Akureyri.

Snæfríður Egilson. (2006). Á heimavelli. Í Rannveig Traustadóttir (ritstjóri), Fötlun, hugmyndir og aðferðir á nýju fræðasviði (bls. 107-121). Reykjavík: Háskólaútgáfan.

Dóra Björg Sigurðardóttir. (2018).

Siðfræði í bókmenntakennslu.

Netla - veftímarit um uppeldi og menntun. Sérrit 2018 - Bókmenntir, listir og grunnpættir menntunar.

Menntavísindasvið Háskóla Íslands. Sótt af http://netla.hi.is/serrit/2018/bokmenntir_listir_menntun/11.pdf

https://doi.org/10.24270/serritnetla.2019.24 